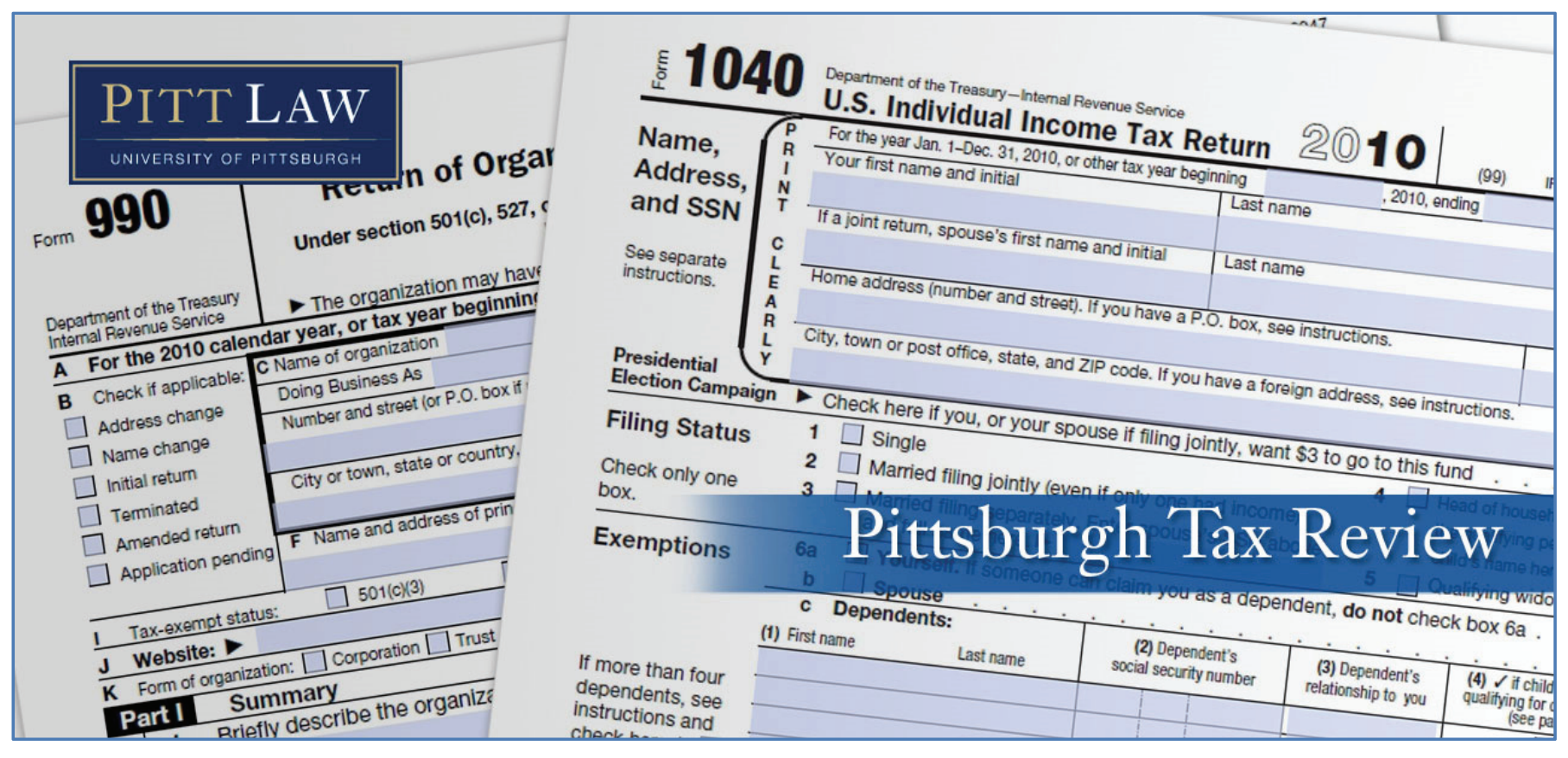

Volume 11 (2014) | ISSN 1932-1821 (print) 1932-1996 (online)

DOI 10.5195/taxreview.2014.29 | http://taxreview.law.pitt.edu

\title{
(cc) EY-NC-ND
}

This work is licensed under a Creative Commons Attribution-Noncommercial-No Derivative Works 3.0 United States License.

\section{UILS D-Sorlf}

This journal is published by the University Library System of the University of Pittsburgh as part of its D-Scribe Digital Publishing Program, and is cosponsored by the University of Pittsburgh Press. 
PITTSBURGH TAX REVIEW

\begin{tabular}{lll}
\hline Volume 11 & Spring 2014 & Issue 2 \\
\hline
\end{tabular}

TABLE OF CONTENTS

ARTICLES

MAINTAINING CLASS ACTIONS IN TAX CASES: WHY

HAVE FEDERAL LITIGANTS BEEN SO MUCH LESS

SUCCESSFUL?

Charlotte Crane.

OFFICERS UNDER THE APPOINTMENTS CLAUSE

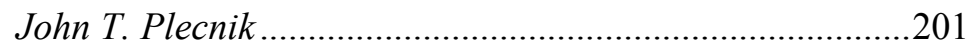

THE UNEASY CASE AGAINST TAX LIEN

SUBORDINATION

Shu-Yi Oei

Pitt Tax Review | ISSN 1932-1821 (print) 1932-1996 (online)

DOI 10.5195/taxreview.2014.29 | http://taxreview.law.pitt.edu 
PITTSBURGH TAX REVIEW

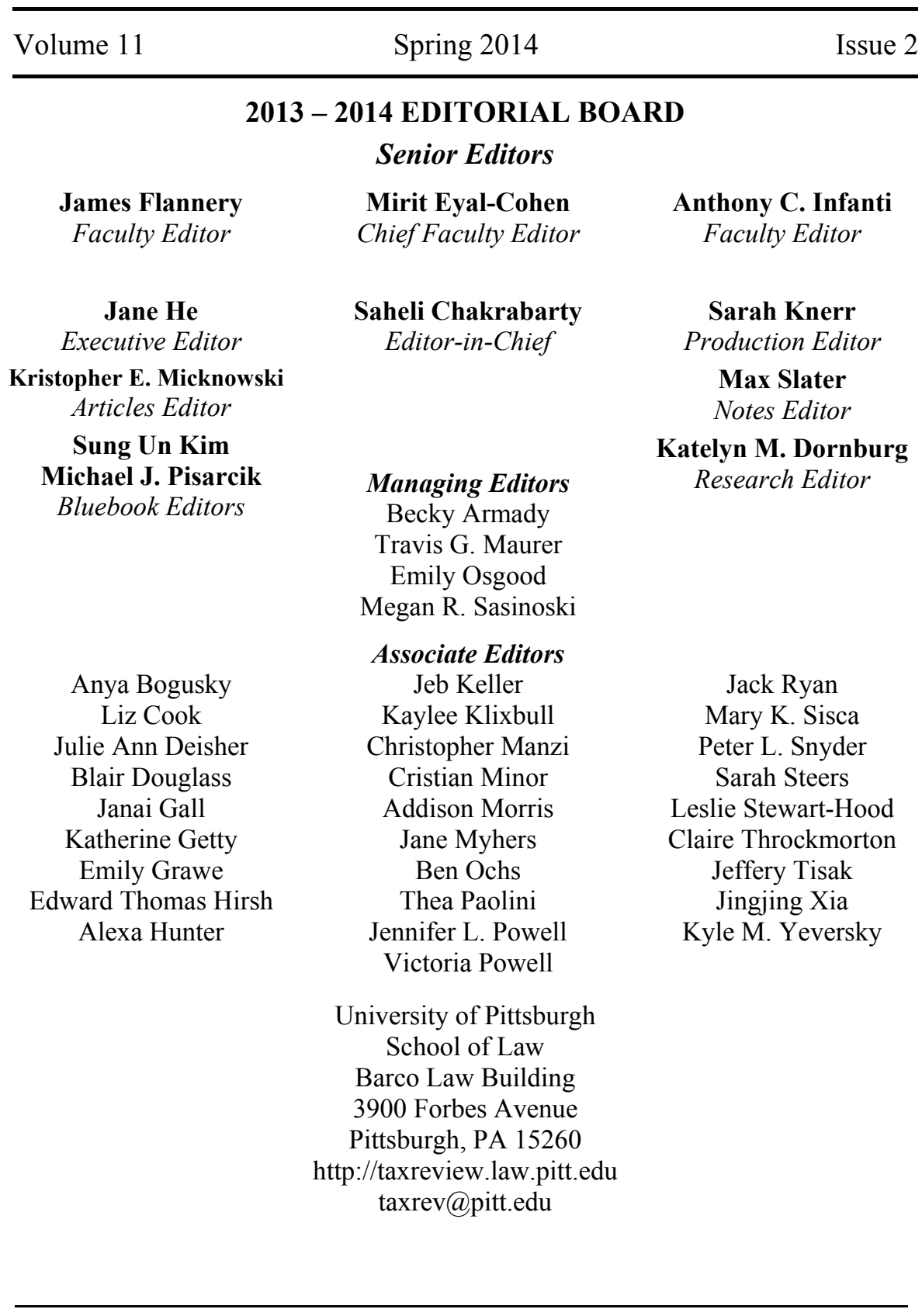

Pitt Tax Review | ISSN 1932-1821 (print) 1932-1996 (online) DOI 10.5195/taxreview.2014.29 | http://taxreview.law.pitt.edu 


\section{General Publication Information}

The Pittsburgh Tax Review is published biannually by the University Library System, University of Pittsburgh. Subscriptions: $\$ 45.00$ per volume for U.S. delivery and $\$ 60.00$ per volume for foreign delivery. Subscriptions are automatically renewed if notice of termination is not received before the expiration of the current subscription period. The Pittsburgh Tax Review is available online through WESTLAW ${ }^{\circledR}$ and LEXIS $^{\circledR} /$ NEXIS $^{\circledR}$ and at http://taxreview.law.pitt.edu. Complete volumes and single issues are available exclusively from the William S. Hein \& Co. Inc.; they can be obtained by mail by writing to William S. Hein \& Co. Inc., 1285 Main Street, Buffalo, NY 14209; by calling William S. Hein \& Co. Inc. at 1-800828-7571; or in electronic format on HeinOnline (http://heinonline.org). Copyright for each work contained in this issue is retained by the author and under a Creative Commons Attribution-Noncommercial-No Derivative Works 3.0 United States License.

Except as otherwise expressly provided, the Pittsburgh Tax Review hereby grants permission for copies of articles to be made for classroom use in nationally accredited law schools, provided (1) copies are distributed at or below cost, (2) author and journal are identified, and (3) proper notice of copyright is affixed to each copy.

Views expressed in the articles, editorial comment, book reviews, notes, and other contributions appearing in the Pittsburgh Tax Review are those of the individual authors and do not necessarily represent the views of the Editorial Board or the University of Pittsburgh School of Law.

\section{Citation References}

All references and citations to sections in this issue are to sections of the Internal Revenue Code of 1986 ("The Code"), as amended, unless otherwise indicated. All references and citations to regulations are to Treasury Regulations under the Internal Revenue Code of 1986, as amended, unless otherwise indicated.

Pitt Tax Review | ISSN 1932-1821 (print) 1932-1996 (online) DOI 10.5195/taxreview.2014.29 | http://taxreview.law.pitt.edu 


\section{Manuscript Submissions}

The Pittsburgh Tax Review invites submissions of unsolicited manuscripts from faculty, judges, and practitioners. The Pittsburgh Tax Review requests that manuscripts be accompanied by an abstract of not more than 200 words describing the contents of the article.

The submissions will be reviewed and decided upon by the Faculty Editors. All citations should conform to The Bluebook: A Uniform System of Citation (19th ed. 2010).

Submissions should be sent to: Editor-in-Chief, Pittsburgh Tax Review, University of Pittsburgh School of Law, Barco Law Building, 3900 Forbes Avenue, Pittsburgh, Pennsylvania, 15260. Electronic submissions are accepted and can be sent to taxrev@pitt.edu. Electronic submissions are also accepted through Express $O^{\mathrm{TM}}$ online submission delivery service. Manuscripts cannot be returned.

Pitt Tax Review | ISSN 1932-1821 (print) 1932-1996 (online) DOI 10.5195/taxreview.2014.29| http://taxreview.law.pitt.edu 